WOMEN WITH BREAST CANCER: FROM SYMPTOMS TO ADJUVANT TREATMENT

\author{
Luciana Martins da Rosa ${ }^{1}$, Vera Radünz ${ }^{2}$
}

\begin{abstract}
${ }^{1}$ Ph.D. in Nursing. Professor in the Department of Nursing at the Federal University of Santa Catarina (UFSC). Florianópolis, Santa Catarina, Brazil. E-mail: luciana.m.rosa@ufsc.br

${ }^{2}$ Ph.D. in Nursing. Professor in the Department of Nursing and in the Post-Graduate Nursing Program at the UFSC. Florianópolis, Santa Catarina, Brazil. Email: radunz@ccs.ufsc.br
\end{abstract}

\begin{abstract}
This descriptive study, with a quantitative approach, identified the social, clinical and demographic profile, and the time interval between the diagnostic and therapeutic stages, from symptoms to adjuvant treatment, of the women with breast cancer treated in an oncology institution in Santa Catarina, Brazil. Data was collected from interviews and the medical records of thirteen women, between August and December 2010. The analysis was supported by scientific recommendations for the treatment of breast cancer, and by descriptive statistics. The results show the illness's high incidence among women between $40-49$ years of age, who are married, and with schooling up to junior high school level. The median time interval until the start of treatment was 245 days, with a further 54 days to the adjuvancy. The findings evidence the advance stage and explain the urgency for the implementation of care for the woman with breast cancer and the National Oncology Care Policy.
\end{abstract}

DESCRIPTORS: Nursing. Breast neoplasms. Delayed diagnosis.

\title{
DO SINTOMA AO TRATAMENTO ADJUVANTE DA MULHER COM CÂNCER DE MAMA
}

RESUMO: Estudo descritivo, com abordagem quantitativa, que identificou o perfil sócio, clínico e demográfico e o intervalo de tempo entre as etapas diagnósticas e terapêuticas, do sintoma ao tratamento adjuvante das mulheres com câncer de mama tratadas em instituição oncológica de Santa Catarina, Brasil. Os dados foram coletados por entrevista e nos prontuários de treze mulheres, de agosto a dezembro de 2010. A análise foi sustentada por recomendações científicas para tratamento do câncer de mama e estatística descritiva. Os resultados demonstram a incidência elevada da doença nas mulheres entre 40-49 anos, casadas e com escolaridade até o ensino fundamental. A mediana dos intervalos de tempo até o início do tratamento foi de 245 dias e mais 54 dias para a adjuvância. Os achados evidenciam o estadiamento avançado e justificam a urgência para a implementação do cuidado à mulher com câncer de mama e da Política Nacional de Atenção Oncológica.

DESCRITORES: Enfermagem. Neoplasias da mama. Diagnóstico tardio.

\section{DEL SÍNTOMA AL TRATAMIENTO ADYUVANTE DE LA MUJER CON CÁNCER DE MAMA}

RESUMEN: Investigación descriptiva, con enfoque cualitativo, que analizó el perfil social, clínico y demográfico, y el intervalo de tiempo, entre las etapas diagnósticas y terapéuticas, del síntoma al tratamiento adyuvante de las mujeres con cáncer de mama tratadas en una institución oncológica de Santa Catarina, Brasil. Los datos fueron colectados mediante entrevista y en los expedientes de 13 sujetos, entre Agosto y Diciembre de 2010. El análisis se sostuvo por las recomendaciones científicas para el tratamiento del cáncer de mama y estadística descriptiva. Los resultados demuestran la incidencia elevada de la enfermedad en las mujeres entre 40-49 años, en las mujeres casadas y escolaridad hasta la enseñanza fundamental. El intervalo de tiempo medio hasta el inicio del tratamiento fue de 245 días y 54 días más para la adyuvancia. Los hallazgos justifican el estadio avanzado y la urgencia para la implantación del cuidado a la mujer con cáncer de mama y de la Política Nacional de Atención Oncológica.

DESCRIPTORES: Enfermería. Neoplasias de la mama. Diagnóstico tardío. 


\section{INTRODUCTION}

Breast cancer has a significant impact on women's health. In Brazil, it is the most common type of cancer among women, apart from non-melanomous skin cancer. The numbers for incidence and mortality in Brazil, published in 2010 by the International Agency for Research on Cancer (IARC), referent to the year 2008, were, respectively, 42,566 and $12,573 .^{1}$

Delays in the diagnosis and start of breast cancer treatment increase the women's anxiety and can impede curative treatments, reducing survival rates. ${ }^{2-3}$ Some studies evidence that a delay of more than three months between the start of the symptoms and the treatment is associated with lower survival rates.-5

With a view to improved survival rates, better prognoses and lower mortality rates for breast cancer, the Brazilian National Cancer Institute (INCA) recommends that initial treatment should take place up to three months after the appearance of the illness's signs and symptoms, that the adjuvant treatment with chemotherapy or hormonotherapy should start up to 60 days after the surgery, and that the adjuvancy with radiotherapy, up to 120 days after the surgery. ${ }^{6}$

Canadian and British studies which investigated the time interval between diagnosis and the start of breast cancer treatment presented an interval of 22 to 36 days. Brazilian studies, undertaken in the states of Paraná and São Paulo, present a period of over 80 days. ${ }^{2-3,5,7-9}$

One may thus ask what the time interval is between the diagnostic and therapeutic stages for the woman treated by the Unified Health System (Sistema Único de Saúde - SUS)? What are these women's social, clinical and demographic characteristics?

Accordingly, the present study aims to identify the social, clinical and demographic profile, and the time interval between the diagnostic and therapeutic stages, from symptoms to adjuvant treatment, for the women with breast cancer treated in an oncology institution in Santa Catarina. This research objective arose as a result of the innumerable reports of delays in diagnosis and treatment for breast cancer, and because of the number of advanced-stage cancers found in a specialized oncological care institution in Santa Catarina, Brazil.
It is noteworthy that in 2002, in this institution which is this study's setting, the most frequent stages were: stage II, $36.6 \%$, and stage III, $21 \%$, with $8.9 \%$ of the hospital medical records not containing information on the staging of the illnesses; ${ }^{10}$ and in 2008 , they were: stage I, $25.5 \%$, and stage II, $23.4 \%$, and the percentage of medical records without information on this had risen to $22.1 \% .^{11}$ In that same year, the stages with the highest percentages were: stage II, $30 \%$; I, $18 \%$; and III, $18 \%$, with $27 \%$ of the medical records not containing information of the disease's stage. ${ }^{11}$

It is considered that the identification of the time intervals can contribute to the development of measures which would make early diagnosis and early initiation of treatment possible, as well as reducing mortality from breast cancer, in accordance with the proposal of the National Oncology Care Policy.

\section{METHOD}

This is a descriptive study with a quantitative approach, carried out in an institution specializing in oncology care in Santa Catarina, Brazil, in the period August - December 2010. It was approved by the Ethics Committee of the institution in which the study was set, under Decision 009/2010. The study followed the legal precepts for carrying out research with human beings. ${ }^{12}$

The following were included in the study: women undergoing adjuvant chemotherapy, attended only by the SUS since their diagnosis with the disease, and who started the treatment with the following therapeutic sequences: neoadjuvant chemotherapy, followed by surgery for removal of the mammary neoplasm nodule, and adjuvant chemotherapy and/or adjuvant radiotherapy (therapeutic scheme I), or surgery for removal of the mammary neoplasm nodule, followed by adjuvant chemotherapy and/or radiotherapy (therapeutic scheme II). Also included were women who started treating the disease with therapeutic scheme I or II in 2009, with attendance exclusively from the SUS, according to the records in their medical records, found with scheduling of post-adjuvancy follow-up, in the period of the study.

Selection of the women undergoing adjuvant chemotherapy was done based on the system for arranging chemotherapy. 36 women were ap- 
proached in the Chemotherapy Center, of whom eight met the inclusion criteria. The exclusions ( 28 women) happened because the diagnostic and/ or therapeutic stages had been carried out with private financial resources or with private health plans.

The selection of the women who started treatment in 2009 was undertaken with a list of 138 names provided by the Informatics Division. After analysis of the medical records, only 24 had been attended exclusively by the SUS. Of these 24 women initially selected, five were met in the period studied, when they were scheduled to be seen in the study's setting.

Thus, the sample totalled 13 women: eight women undergoing adjuvant chemotherapy and five in post-adjuvancy follow-up. Data collection was carried out via interviews with closed questions, and from the data contained in the women's medical records. It was decided to associate these two collection techniques due to the fact of the medical records not recording all the variables established to be investigated by this study. This association allowed the data which had not been recorded in the medical records to be identified directly with the women.

After the women's selection as study subjects and their acceptance to be so, this acceptance being recorded by means of their signing the Terms of Free and Informed Consent, dates and times were arranged for holding interviews with each woman. Collection of data from the medical records had been undertaken prior to the holding of the interviews.

The data collected was recorded in a specific instrument. The variables investigated were: age, city of origin, level of schooling, profession/ occupation, date of the start of signs and symptoms in the woman's perception, date of the mammography or ultrasonography, date of the biopsy, date of the biopsy report, dates of the start and end of the neoadjuvant chemotherapy, date of the surgery, date of the start of the adjuvant chemotherapy or radiotherapy, the mammographic follow-up, lymphadenectomy, who detected the disease, signs and symptoms when the disease was detected, and the reasons explaining the time interval between the diagnostic and therapeutic stages, in the woman's perception.

The collected and recorded data was typed into Microsoft Excel spreadsheets. Based on these spreadsheets, the time intervals between the diagnostic and therapeutic stages were calculated, as was the total time from symptoms to adjuvant treatment, in accordance with each therapeutic scheme, I or II. Also calculated were the minimum and maximum times between each stage, and the mean and median times.

The analysis of the data was supported based on the scientific recommendations indicated for the treatment of breast cancer, the results of studies on the issue in question, and descriptive statistics.

\section{RESULTS}

The number of subjects totalled a sample of 13 women. Of the 13 hospital records investigated, six presented records related to the origin, schooling, profession/occupation and marital status which differed from what was reported in the interviews. Two women, when they opened the medical records, had given the addresses of relatives resident in Florianópolis and Palhoça. They stated that they had done so to speed up the care, as in their cities of origin, Blumenau and Laguna, the diagnostic process was very slow. In relation to the other data found which differed from the women's reports, they could not explain the reasons for the doubtful records. Hence, it may be deduced that the professionals who made the records had made mistakes.

Of the five women who started treating the illness in 2009, one confirmed that she had undertaken all the stages for diagnosis and treatment via the SUS; two stated that they had had diagnostic tests and consultations using private services; one undertook tests, consultations and surgery using private financial resources; and one undertook tests and consultations using private health insurance. It is made clear that these women who undertook diagnostic and therapeutic stages without using the SUS were kept in the study, as there were records in the medical records of attendance exclusively by the SUS.

The lack of records in the medical records concerning the diagnostic and therapeutic stages undertaken outside of the SUS is due to the fact that they had been undertaken prior to the beginning of the attendance in the institution where this study was set (the opening of the hospital records), in line with reports. The records of these women's clinical histories started from the report on the anatomopathological report on the breast surgery, there not being records on the start of the disease and how the diagnostic process was, prior to entering the institution. 
The age ranges met covered: seven women between 40 and 49 years of age $(53.8 \%)$, three women from 50 to 59 years of age $(23.1 \%)$, two women from 60 to 69 years of age $(15.4 \%)$ and one woman aged between 30 and 39 (7.7\%).

Regarding marital status, the findings show that more than half the women are married, seven women (53.8\%); two women are separated $(15.4 \%)$; two are widows $(15.4 \%)$; one is single $(7.7 \%)$; and one is in a stable relationship $(7.7 \%)$. It was not possible to make any correlation with other variables, as a result of the small number of subjects found.

Only one woman reported being educated to university level (7.7\%); five women reported being educated to senior high school level (38.4\%); six, to junior high school level (46.2\%); and one stated that she was illiterate $(7.7 \%)$.

It was observed that the most frequent professions/occupations found were those related to lower educational levels. Six women reported professions/occupations related to domestic activities $(46.2 \%)$; one was a nursing technician $(7.7 \%)$; one was an administrative assistant $(7.7 \%)$; one worked in agriculture $(7.7 \%)$; one was an accountant (7.7\%); one was a fisherwoman $(7.7 \%)$; one, a masseuse $(7.7 \%)$; and one had a small business $(7.7 \%)$.

The most frequent stages were stage II $(46.1 \%)$, with six women, and stage III $(46.1 \%)$, also with six women. Stage IV was identified in one woman $(7.7 \%)$.

Regarding where they were from, four women are from the city of Florianópolis (30.7\%), four from Palhoça (30.7\%), two from São José (15.5\%), one from Laguna $(7.7 \%)$, one from Garopaba $(7.7 \%)$ and one from Blumenau $(7.7 \%)$.
All the women investigated $(100 \%)$ by this study detected changes in the breast which led to the investigation and to the diagnosis of breast cancer: ten (76.8\%) felt a nodule, two had felt pain/ stabs of pain $(15.5 \%)$ and one perceived retraction of skin on the breast $(7.7 \%)$. It is emphasized that all $(100 \%)$ carried out periodical yearly or bi-yearly check-ups, in line with medical recommendation. Two $(15.5 \%)$ mentioned having had previous mammographies which indicated the presence of a nodule. They also noted that in spite of the detection of the image, the doctor at the health clinic had said that there was no need for further tests or care.

Therapeutic scheme I was carried out by four women $(30.7 \%)$ and therapeutic scheme II by nine women $(69.3 \%)$, with adjuvant chemotherapy being undertaken by 12 women $(92.3 \%)$ and adjuvant radiotherapy by one woman $(7.7 \%)$. All $(100 \%)$ received axillary removal, which confirms the compromising of the axillary lymphatic system with neoplastic cells, the risk of distant metastases and the reduction in survival rates.

Table 1 presents the time intervals between the appearance of symptoms and the adjuvant treatment of the women with breast cancer investigated in this study. The greatest time intervals were identified between: the symptom and the screening, which varied between two and 1460 days; the biopsy report and the neoadjuvancy, which varied between 34 and 135 days; and the biopsy report and the surgery, which varied between three and 291 days. The median time interval found between the appearance of the signs and symptoms and the beginning of treatment surgical or with neoadjuvant chemotherapy - was 245 days, and the median time interval between the surgery and the adjuvancy with chemotherapy or radiotherapy, was 54 days.

Table 1 - Time intervals, in days, between the appearance of the symptoms and the chemotherapy or radiotherapy for women with breast cancer attended by the SUS. Florianópolis-SC, 2010

continue

\begin{tabular}{|c|c|c|c|c|c|c|c|c|c|c|c|}
\hline \multirow{2}{*}{$\mathbf{n}$} & \multirow[t]{2}{*}{ City of origin } & \multicolumn{10}{|c|}{ Time intervals } \\
\hline & & $1^{*}$ & $2 \dagger$ & $3 \ddagger$ & $4 \S$ & $5 \|$ & $6 \pi$ & $7^{* *}$ & 8†† & 9ł‡ & $10 \S \S$ \\
\hline 1 & Florianópolis & 1460 & 33 & 4 & 64 & 86 & 7 & - & 105 & 1561 & 1759 \\
\hline 2 & Florianópolis & 6 & 7 & 5 & \|\| & \|\| & \|\| & 115 & 74 & 133 & 207 \\
\hline 3 & Florianópolis & 90 & 42 & 6 & 34 & 156 & 36 & - & 54 & 172 & 418 \\
\hline 4 & São José & 2 & 8 & 4 & 87 & 50 & 25 & - & 23 & 101 & 199 \\
\hline 5 & Palhoça & 50 & 92 & 30 & \|\| & \|\| $\mid$ & $\|||$ & 78 & 62 & 250 & 312 \\
\hline 6 & Palhoça & 510 & 12 & 14 & ||| & \|\| & ||| & 3 & 55 & 539 & 594 \\
\hline 7 & Blumenau & 210 & 0 & 10 & \|\| & $|\||$ & \|\| & 25 & 35 & 245 & 280 \\
\hline
\end{tabular}




\begin{tabular}{|c|c|c|c|c|c|c|c|c|c|c|c|}
\hline \multirow{2}{*}{$\mathbf{n}$} & \multirow[t]{2}{*}{ City of origin } & \multicolumn{10}{|c|}{ Time intervals } \\
\hline & & $1^{*}$ & $2 \dagger$ & $3 \ddagger$ & $4 \S$ & $5 \|$ & $6 \pi$ & $7^{* *}$ & $8 † \dagger$ & $9 \ddagger \ddagger$ & $10 \S \S$ \\
\hline 8 & Florianópolis & 30 & 12 & 5 & \|\|$\|$ & \|\|$\|$ & $\mid\|\|$ & 36 & 76 & 83 & 159 \\
\hline 9 & Palhoça & 510 & 18 & 3 & III & III & \|\| & 67 & 49 & 598 & 647 \\
\hline 10 & São José & 23 & 10 & 17 & \|\| $\mid$ & \|\| $\mid$ & \|\|$\|$ & 25 & 53 & 75 & 128 \\
\hline 11 & Laguna & 60 & 73 & 31 & \|\| $\mid$ & \|\|$\|$ & \|\|$\|$ & 291 & 85 & 455 & 540 \\
\hline 12 & Garopaba & 150 & 431 & 43 & |l|| & \|\| & \|\| & 50 & 46 & 674 & 720 \\
\hline \multirow[t]{4}{*}{13} & Palhoça & 23 & 12 & - & 135 & 63 & 34 & - & 36 & 170 & 303 \\
\hline & शा & $2-1460$ & $0-431$ & $0-43$ & 34-135 & $50-156$ & $7-36$ & $3-291$ & 23-105 & $75-1561$ & $128-1759$ \\
\hline & *** & 60 & 18 & 10 & 45,5 & 75 & 30 & 50 & 54 & 245 & 312 \\
\hline & ††† & 240 & 58 & 13 & 80 & 89 & 26 & 77 & 58 & 389 & 482 \\
\hline
\end{tabular}

* 1 - Interval: symptom to screening † 2 - Interval: screening to biopsy; $\ddagger 3$ - Interval: biopsy to biopsy report; § 4 - Interval: biopsy report to neoadjuvancy; || 5 - Interval: beginning to end neoadjuvancy; 9 - Interval: end neoadjuvancy to surgery; ${ }^{* *} 7$ - Interval: biopsy

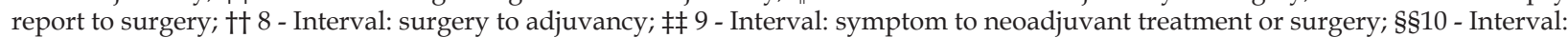
symptom to adjuvancy; | | | | women who did not undertake neoadjuvant treatment; 9 | minimum and maximum time found between all the diagnostic and therapeutic stages; ${ }^{* *}$ median found between all the diagnostic and therapeutic stages; $† \dagger+m e a n$ time found between all the diagnostic and therapeutic stages.

The reasons which explain the delays for the diagnosis and start of treatment, in the perception of the women, were related to:

- difficulty in scheduling tests, such as: mammographies, ultrasonographies, biopsies, electrocardiograms, tomographies, radiographies and bone scintigraphies.

- evidence from images or symptoms which were not taken into account by the doctors. The women asserted that previous tests indicated changes in the image, but no further test was requested to complement the clinical evaluation.

- difficulty in scheduling consultations with mastologists and oncologists.

- lack of information on the part of the woman on breast cancer and women's health, because they had not sought health attendance as soon as symptoms started, and because of believing that the symptoms were not dangerous.

- difficulty in scheduling surgery, due to there not being a space in the health system for the surgery to be carried out soon after the illness's diagnosis; delay in the issuing of the biopsy report; and the need to repeat the biopsy, because of there being a long interval between biopsies resulting from the scheduling and issuing of the reports.

- difficulty in the immediate scheduling of the chemotherapy.

- delay in referrals using the SUS for women who are not resident in Florianópolis-SC, Brazil.

\section{DISCUSSION}

The finding related to age range re-affirmed the higher incidence over the age of 40 , as pre- sented by other studies. ${ }^{13-15}$ However, the age range of 40-49 years is generally in second place in incidence in the studies. In this study, it was in first place. This indicates the need to broaden access to the health system for women over 40 years old, as instituted by Law n.11,664. This law assures the mammogram to all women over 40 years old, and their referral to services of greater complexity, depending on the need for further forms of diagnosis, treatment and post-treatment follow-up, which cannot be undertaken in the center where the initial attendance was given. ${ }^{16}$

Regarding the level of schooling found, the results showed the need for implanting educational policies which would make it possible to raise the level of schooling in the population, given that the higher the schooling, the lower the stages of the illnesses and the fewer the number of deaths. Schooling is also associated with better socioeconomic standards, which also reduces and/or favors the treatment of the comorbidities. ${ }^{17-18}$

Changes in educational policies should also include the understanding, from childhood, of concepts on health, illness, quality of life, risk factors for chronic illnesses, and the adoption of habits which are good for life and health. Both informing and educating are alternatives which are efficacious for the population's health.

The raising of women's level of schooling and socio-economic standard contributes to better survival rates, and reduction in cases of deaths, early retirements, and public expenditure on more expensive treatments. Raising levels of schooling would also contribute to women being able to have professions/occupations which offer better salaries and, consequently, better living and health conditions. 
Comparing the findings relevant to the illnesses' staging with the hospital records for cancer for 2002 and $2008,,^{10-11}$ a fall was observed for 2008 and a rise for 2009. The reduction I 2008 may have been caused by the number of medical records which did not present the illnesses' staging, which corresponded to $22.1 \%$ of the hospital records investigated.

In relation to where the patients were from, the results indicate the women resident in Florianópolis and Palhoça have greater access to carrying out the diagnostic and therapeutic stages for the control of cancer when using the SUS alone. This analysis is based on the principle that the study setting has, obligatorily, to attend by the SUS the cases of cancer from the 22 municipalities close to Florianópolis. Thus, taking into account the already-mentioned number of exclusions related to the use of private resources, it may be deduced that the exclusions relate to the women resident in the other municipalities, as a result of the difficulty found for scheduling tests and surgery, as mentioned by the women who were subjects in this study, when they explained the reasons for the delay in the diagnosis and start of the treatment for the illness.

Regarding the detection of the disease based on the women's own assessments, the reality found explains the advanced cases of illness found in the study setting. For early diagnosis, what is needed is the detection of the illness by screening, not by self-examination or by touch examination by another. The reality found indicates the unpreparedness of the health system for early diagnosis and for the adoption of efficient procedures which would make better prognoses possible.

The dissemination of mammary carcinomas occurs through local invasion, by the lymphatic or hematogenous network. In $30 \%$ to $50 \%$ of the cases, there is compromising of the axillary lymph nodes at the time of the diagnosis, with regional metastases indicating the metastatic potential for distant and systemic spread. Women with one to three compromised lymph nodes have a $60 \%$ rate of survival at 10 years. This rate falls to $20 \%$ in those women who had 3 to 4 lymph nodes with metastases at the time of the diagnosis. Around $30 \%$ of the women without axillary metastases later develop systemic metastases, which indicates that a large proportion of breast carcinomas are already systemic diseases at the time of the diagnosis. ${ }^{19}$
Analyzing the time intervals presented in table 1, it was observed that the time lost between the symptoms and the beginning of treatment, whether surgical or through neoadjuvant chemotherapy, is high, contributing to the progression of the disease and the appearance of the metastases. Only two women (15.4\%) started treatment within the recommended time interval, that is, up to three months after the beginning of the signs and symptoms. ${ }^{6}$ With the other eleven women $(84.6 \%)$, the beginning of the treatment exceeded the technical recommendation, which, once again, indicates a condition for the advanced staging of the disease - and worse prognoses.

Following, in descending order, the strongest influences on the time interval from symptom to starting of treatment, the findings point to the difficulties which the women have in undertaking the screening and the difficulty in accessing attendance by the oncologist, that is, in getting the treatment started. In spite of the median not indicating difficulty in accessing the mastologist, it can be observed that some women experienced a prolonged time interval in managing to undertake the breast biopsy. For four women, this period exceeded 30 days.

A maximum interval of up to 60 days after surgery is recommended for the beginning of the adjuvancy with chemotherapy. ${ }^{6}$ Of the 13 women included in this study, 12 had undergone this form of therapy, of whom five had not started the adjuvancy within the recommended time interval. One woman had undergone adjuvancy with radiotherapy, and in this case the time called for, of up to 120 days, ${ }^{6}$ was met.

It is therefore considered that the context presented here - of delays in the time intervals between the diagnostic and therapeutic stages - is incompatible with raising survival rates, reducing the degrees of staging of breast cancer and the physical, psychological and social mutilations suffered by the women. Although the findings indicate that the interval for initiating the adjuvancy is close to that called for, the start of the treatment is not, which means that the risk of metastatic disease already existed prior to the stage of adjuvancy.

Comparing the time intervals between screening and beginning of the treatment in this study in Florianópolis-SC, Brazil, with Brazilian studies carried out in Londrina in the state of Paraná (PR) from January 2003 to October 2004 (180 medical records), ${ }^{8}$ and São Paulo, in 2006 
(68 medical records), ${ }^{9}$ both of which investigated the medical records of women attended by the public health system, the time intervals found in the three studies were, respectively: median of 99 days (or mean of 148 days), mean of 175 days (this study did not calculate the median), ${ }^{8}$ and median of 143 days. ${ }^{9}$

It may be observed that in Florianópolis-SC, the time interval between the screening and the start of treatment is presented as slightly better than for women from elsewhere in the state of Santa Catarina. This time interval, however, does not include the time between symptom and screening. The summary of this time interval shows how much remains to be done to obtain time intervals within the scientific recommendations and in the quest for quality of life and respect for women and society.

In this context, it should again be emphasized that the greater time intervals were found between the symptom and the screening, and between the biopsy report and the initiation of treatment. This finding reflects the need to inform women in Santa Catarina about women's health and breast cancer, and shows the need for rapid and resolutive access to health, the need to broaden the number of specialized health care professionals so as to attend the high number of suspected and confirmed cases of women with breast cancer. Increasing the number of professionals working in medium- and high-complexity services in the health system would speed up diagnosis and the start of treatment, and consequently would contribute to early diagnosis, to the carrying-out of curative treatments, to reducing costs with more complex therapies, to raising survival rates and reducing mortality rates.

The findings related to the time intervals between the various diagnostic and therapeutic stages are contrary to the proposals for oncological assistance defined by Law 11,664 and by the National Oncology Care Policy ${ }^{16,20}$ and, besides the time and survival aspects, need to be attent to the women's quality of life. The later the diagnosis and the start of treatment, the worse is the quality of life of the women with breast cancer, as well as of their families and society, which suffer the consequences of the health system's improvidence. ${ }^{21}$

The reasons the women present for the delay in diagnosis and start of treatment for breast cancer show, yet again, the obstacles in the referral flow between the low, medium and high complexity services for health care assistance through the SUS. The obstacles are mainly related to the carrying-out of tests and to specialized care. The technical unpreparedness and some professionals' lack of training may be contributing to the progression of the disease, and to incorrect and late diagnoses.

In relation to this study's limitations, one can define the small number of women included as subjects of the research. The definition of exclusive attendance by the SUS as an inclusion criteria limited the number of inclusions. However, as the study setting is an institution which obligatorily has to attend demand from the SUS, referent to the Greater Florianópolis, in the state of Santa Catarina, ${ }^{22}$ it was not expected that the majority of women under treatment in the period of the study would have undertaken stages using private financial resources or private health insurance.

\section{CONCLUSION}

The results investigated here - in the time interval from symptom to treatment, for breast cancer, indicate the difficulty which women encounter in accessing the SUS. The reality of prolonged periods of time between the various referrals between the diagnostic and therapeutic stages contributes to the disease's advance and to advanced staging. The findings demonstrate that the health system contributes to worse rates of survival and that society suffers the consequences of this improvidence.

It is necessary to adopt strategies for reducing the time intervals up to the start of treatment for breast cancer. For the achievement of such changes, the following are recommended: the training and qualification of health care professionals, at the different levels of training; the contracting of sufficient professionals to meet existing health/illness demands; and the acquisition and maintenance of appropriate equipment and physical areas for the various forms of assistance.

Another important point for change would be the revision of the structuring of the current model adopted by the SUS, which requires various referrals between the various health services which comprise it, depending on the health actions' complexity. Unfortunately the system does not provide means for the woman to cover the levels of care in a short space of time, such that she can impede the advance of the breast cancer, the poor prognosis and the suffering. These referrals, in the current model, increase the time intervals, principally 
because of the delays in scheduling between the various diagnostic and therapeutic stages.

Higher levels of education and socioeconomic standard contribute to the reduction of advanced cases of breast cancer, and consequently to reduction in the cases of premature deaths. It is therefore essential that changes in social and educational policies should occur in Brazilian territory as, Santa Catarina being one of the more developed states in Brazil, the reality in other, less developed, states, may be more critical than that investigated in this study.

The findings show how the reality of health in Santa Catarina, as described here, is behind scientific discoveries and current scientific recommendations. Much remains to be done to implant a system capable of the early detection of breast cancer, thus contributing to the reduction of advanced stages and higher survival rates.

As a recommendation for the institution where the study was set, it is suggested that the same cold maintain up-to-date a computer database, and that the records in the medical records should be reviewed. These measures can help in the assessment of the work process and in the meeting of the scientific recommendations called for for the treatment of breast cancer and all the other types of cancer.

\section{REFERENCES}

1. International Agency for Research on Cancer. World Health Organization GLOBOCAN 2008. Cancer incidence and mortality Worldwide 2008. [online]. 2010 [acesso 2010 Dez 12]. Disponível em: http:/ / globocan.iarc.fr/factsheets/populations/factsheet. asp?uno $=76$

2. Rayson D, Saint-Jacques N, Younis T, Meadows J, Dewar R. Comparison of elapsed times from breast cancer detection to first adjuvant therapy in Nova Scotia in 1999/2000 and 2003/04. CMAJ [online]. 2007 Jan [acesso 2009 Mar 09];176(3):32732. Disponível em: http://www.cmaj.ca/cgi/ reprint/176/3/327.pdf

3. Reed AD, Williams RJ, Wall PA, Hasselback P. Waiting time for breast cancer treatment in Alberta. Can J Public Health. 2004 Set-Out;95(5):341-5.

4. Arndt V, Stürmer T, Stegmaier C, Ziegler H, Becker A, Brenner H. Provider delay among patients with breast cancer in Germany: a population-based study. J Clinic Oncol [online]. 2003 Abr [acessed 2009 Mar 09];21(8):1440-6 Available:: http://jco.ascopubs. org/cgi/content/full/21/8/1440

5. Montella M, Crispo A, Botti G, De Marco M, De Bellis G, Fabbrocini G, et al. An assessment of delays in obtaining definitive breast cancer treatment in Southern Italy. Breast Cancer_Res Treat. 2001 Apr;66(3):209-15.

6. Instituto Nacional de Câncer José Alencar Gomes da Silva. Recomendações para redução da mortalidade por câncer de mama no Brasil: balanço 2012. Rio de Janeiro (RJ): INCA; 2012.

7. Mayo NE, Scott SC, Shen N, Hanley J, Goldberg MS, MacDonald N. Waiting time for breast cancer surgery in Quebec. CMAJ [online]. 2001 [acessed 2009 Mar 09];17;164(8):1133-8. Available:: http:// www.pubmedcentral.nih.gov/articlerender. fcgi? artid=80969

8. Souza VO, Grando JPS, Filho JO. Tempo decorrido entre o diagnóstico de câncer de mama e o início do tratamento, em pacientes atendidas no Instituto de Câncer de Londrina (ICL). RBM Rev Bras Med [online]. 2008 Jun [acesso 2009 Mar 08];65(5):1358. Disponível em: http://bases.bireme.br/cgibin/wxislind.exe/iah/online/?IsisScript=iah/ iah. $x$ is\&src $=$ google\&base $=$ LILACS\&lang= $\mathrm{p} \& \mathrm{nextAction}=1 \mathrm{nk} \& \mathrm{exp} \mathrm{r}$ e a r c h $=$ 485556\&indexSearch=ID

9. Trufelli DC, Miranda VC, Santos MBB, Fraile NMP, Pecoroni PG, Gonzaga SFR, et al. Análise do atraso no diagnóstico e tratamento do câncer de mama em um Hospital Público. Rev Assoc Med Bras [online]. 2008 Jan-Fev [acesso 2009 Mar 09]; 54(1):72-6. Disponível em: http:/ / www.scielo. br / scielo.php?script=sci_arttext\&pid=S010442302008000100024\&lng=en\&nrm=iso\&tlng=pt

10. Serrano AI, D'Orsi E, Giordani-Serrano TR. Monitorando o cuidado: análise do registro hospitalar de câncer do CEPON, de 2000 a 2002. Florianópolis (SC): SES/SC/Insular; 2007.

11. Ministério da Saúde (BR). Integrador Registro Hospitalar do Câncer. Tabulador hospitalar: base do Estado: SC [online]. [acesso 2011 Mar 24]. Disponível em: http://irhc.inca.gov.br/cgi-irhc/dh?rhchos/ $\mathrm{SC} / \mathrm{rhc}$

12. Ministério da Saúde (BR). Conselho Nacional de Saúde. Resolução n ${ }^{0}$ 196/96: Dispõe sobre pesquisa envolvendo seres humanos. Brasília: Ministério da Saúde; 1996.

13. Flores-Luna L, Salazar-Martínez E, Duarte-Torres RM, Torres-Mejía G, Alonso-Ruiz P, LazcanoPonce E. Factores pronósticos relacionados con la supervivencia del cáncer de mama. Salud Públic Méx [online]. 2008 Abr [acess 2009 Out 11]; 50(2):119-25. Disponíble en: http:/ / www.scielosp. org/scielo.php?script=sci_arttext\&pid=S003636342008000200005\&lng=en

14. Cintra JRD, Guerra MR, Bustamante-Teixeira MT. Sobrevida específica de pacientes com câncer de mama não-metastático submetidas à quimioterapia adjuvante. Rev Assoc Med Bras [online]. 2008 Ago [acesso 2009 Out 11]; 54(4):339-46. Disponível 
em: http://www.scielo.br/scielo.php?script=sci arttext\&pid=S0104-42302008000400020\&lng =en

15. Ministério da Saúde. Instituto Nacional do Câncer. Câncer de mama [online]. 2010. [acesso 29 Jan 2010]. Disponível em: http:/ / www.inca.gov.br

16. Presidência da República (BR). Casa Civil. Subchefia para Assuntos Jurídicos. Lei n.11.664, de 29 de abril de 2008. Dispõe sobre a efetivação de ações de saúde que assegurem a prevenção, a detecção, o tratamento e o seguimento dos cânceres do colo uterino e de mama, no âmbito do Sistema Único de Saúde - SUS. Brasília: 2008.

17. Fisch T, Pury P, Probst N, Bordoni A, Bouchardy C, Frick $\mathrm{H}$, et al. Variation in survival after diagnosis of breast cancer in Switzerland. Ann Oncol. [online]. 2005 Dec [acessed 2009 Out 15];16(12):1882-8. Epub 2005 Oct 10. Available:: http://annonc. oxfordjournals.org/cgi/content/full/16/12/1882

18. Louwman WJ, Van de Poll-Franse LV, Fracheboud J, Roukema JA, Coebergh JW. Impact of a programme of mass mammography screening for breast cancer on socio-economic variation in survival: a population-based study. Breast Cancer Res Treat. [online]. 2007 Nov [acess 2009 Set 08]; 105(3):369-75. Available: http:// www.pubmedcentral.nih.gov/articlerender. fcgi? tool=pubmed\&pubmedid $=17211536$
19. Schmitt FE, Gobbi H. Mama. In: Bogliolo L, editor. Patologia. Rio de Janeiro: Guanabara Koogan; 2006. p. 613-42.

20. Ministério da Saúde (BR). Portaria n. 2.439, de 8 de dezembro de 2005. Institui a política nacional de atenção oncológica: promoção, prevenção, diagnóstico, tratamento, reabilitação e cuidados paliativos, a ser implantada em todas as unidades federadas, respeitadas as competências das três esferas de gestão. Diário Oficial da República Federativa do Brasil, 9 Dez 2005. Seção 1, p. 80-1.

21. Silva G, Santos M A. "Será que não vai acabar nunca?": perscrutando o universo do pós-tratamento do cancêr de mama. Texto Contexto Enferm. [online]. 2008 Set [acesso 2012 Out 26]; 17(3):561-8. Disponível em: http://www.scielo.br/scielo.php?script=sci_ arttext\&pid=S0104-07072008000300018\&lng=pt

22. Secretaria de Estado da Saúde de Santa Catarina. Secretaria de Estado do Planejamento. Fundação de Apoio ao HEMOSC e CEPON. Contrato de Gestão $\mathrm{n}^{\mathrm{o}}$ 001/2007 de 19 de dezembro 2007. Contrato de Gestão que entre si celebram, o Estado de Santa Catarina, por intermédio da Secretaria de Estado da Saúde e a Fundação de Apoio ao HEMOSC e CEPON, com a interveniência da Secretaria de Estado do Planejamento; 2007 [acesso 2013 Mai 03]. Disponível em: http://alfa.locadados.com.br/ fahece/ wp-content/uploads/HEMOSC_001.pdf 